\title{
Kerkwees in die voetspore van Christus volgens Efesiërs 4 en 5
}

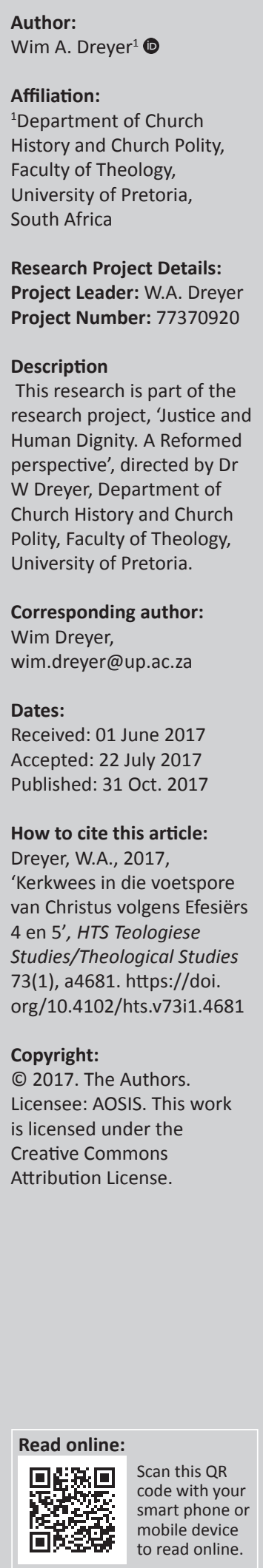

This contribution contains a sermon delivered as opening address to the 71st General Assembly of the Nederduitsch Hervormde Kerk van Afrika (NHKA). For the last twenty years the NHKA had been involved in a process of ecclesial transformation, based on fundamental shifts in ecclesiology. This opening address reflects on the nature and calling of the church in light of Ephesians 4 and 5, with the specific focus on 'being church in the footsteps of Christ'. Much emphasis is placed on the verb 'peripateo' which appears five times in these two chapters. It is suggested that it could be translated as 'following in the footsteps of someone' and that this has very specific implications for being church in the 21st century. Ephesians 4 and 5 articulate being church in the footsteps of Christ in terms of unity, holiness, love, light and wisdom.

\section{Inleidend}

Die Nederduitsch Hervormde Kerk van Afrika (hierna: Hervormde Kerk) én Hervormde teologie ${ }^{1}$ is versigtig om groot en finale uitsprake oor God te maak (Van Huyssteen 1986:159). Ons is diep bewus van die oneindige verskil tussen God en mens (Barth 1968:225): God is almagtig, ons is magteloos. God is heilig, ons is sondig. God is ewig, ons is tydelik. God is altyd anders as wat ons dink. Daarom moet ons meer stilbly, meer luister en met groter beskeidenheid oor God praat. Soos Augustinus ${ }^{2}$ ons geleer het: Ons moet minder oor God praat en meer met God praat.

Ten spyte van ons beperkte vermoëns en gebrekkige kennis, is die evangelie selfs vir 'n kind verstaanbaar. Martin Luther ${ }^{3}$ het by geleentheid geskryf dat ons God moet dank dat selfs 'n kind die evangelie kan verstaan en deel van die kerk van Christus kan wees. Die evangelie is vir die eenvoudigste mens verstaanbaar omdat God se Woord in menslike woorde na ons toe kom en deur alledaagse woorde en beelde God se wonderdade verkondig. ${ }^{4}$ Jesus se gelykenisse is hiervan 'n pragtige voorbeeld. Jesus het eenvoudige beelde, gelykenisse en metafore gebruik om aan die mense te verduidelik dat God se koninkryk 'n werklikheid is.

Die afgelope drie jaar het die Kommissie van die Algemene Kerkvergadering en baie Hervormde gemeentes van'n sentrale metafoor of beeld gebruik gemaak om op 'n eenvoudige en verstaanbare manier uitdrukking te gee aan ons verstaan van kerkwees en Christenwees, te wete Kerkwees in die voetspore van Christus. Dit is ook die tema van die een en sewentigste Algemene Kerkvergadering van die Nederduitsch Hervormde Kerk van Afrika.

Om Jesus te volg word op verskillende maniere in die Nuwe Testament verwoord. In Markus 8:34 sê Jesus byvoorbeeld:

As iemand agter My aan wil kom, moet hy homself verloën, sy kruis opneem en My volg; want wie sy lewe vir homself wil behou sal dit verloor, maar wie sy lewe ter wille van My en die evangelie verloor, sal dit behou.

Die risiko wat dit inhou om Christus te volg, word duidelik as ons in die boek Handelinge lees dat die eerste Christene bekend was as 'mense van die Weg':

- In Hand. 9:2 en 22:4 lees ons dat die mense van 'die Weg' vervolg en doodgemaak is.

1.In 2017 vind die Eeufees van die Fakulteit Teologie plaas. Die Ned. Hervormde Kerk van Afrika lei sedert 1917 sy teologiese studente aan die Universiteit van Pretoria op. Prof. J. Buitendag, Dekaanvan die Fakulteit, ontvang tydens die 71ste Algemene Kerkvergadering die HCM Fourie Erepenning vir die bevordering van reformatoriese teologie.

2.Sien byvoorbeeld Augustinus se Confessiones, waarin dit duidelik word dat teologie nie in die eerste plek 'n gesprek oor God is nie, maar eerder'n gesprek met God.

3.Luther(1537), Schmalkaldische Artikel'... dank God dat selfs ' $n$ kind wat sewe jaar oud is verstaan wat die kerk is, naamlik ' $n$ heilige (gemeenskap van) gelowiges en skape wat luister na die stem van hulle Herder'. Die NHKA herdenk in 2017, saam met kerke wêreldwyd, 500 jaar van Kerkhervorming.

4.Metaforiese spreke sê die onsêbare, dit praat na anologie van die bekende oor die onbekende (sien Dreyer 1995:800).

Note: This article is a reworked version of the opening address delivered at the 71st Assembly of the Netherdutch Reformed Church on Sunday, 02 October 2016. 
- In Hand. 19:9 lees ons dat die mense van 'die Weg' belaglik gemaak en gespot is oor hulle geloof en lewenstyl.

- In Hand. 19:23 lees ons dat daar betogings en opstande teen die mense van 'die Weg' in Efese was.

- In Hand. 24:14 lees ons dat Paulus deur Feliks, die Romeinse goewerneur in Jerusalem, verhoor is. Paulus getuig tydens die verhoor dat hy God dien volgens 'die Weg', welbewus dat dit vir hom vervolging en die doodstraf kon meebring.

In die 1983 uitgawe van die Bybel in Afrikaans lees ons nie meer van die eerste Christene as 'mense van die Weg' nie, omdat dit met die frase 'die leer van Christus' vertaal is. Dit is jammer, omdat iets van die eerste Christene se lewenswyse as 'mense van die Weg' verruil is vir 'n meer rasionele verstaan van Christenwees. Vir baie lank het kerke in die reformatoriese tradisie groter klem op die suiwer Christelike leer geplaas as op dissipelskap en 'n Christelike lewenstyl, ten spyte daarvan dat Jesus ons leer dat Hy 'die Weg, die Waarheid en die Lewe' is (Joh. 14:6). Die effek daarvan was 'n oordrewe rasionele benadering tot geloof.

Daar is heelwat teksgedeeltes in die Bybel wat ons help om in Christus se voetspore te volg. Vandag val die fokus op die Brief aan die Efesiërs, veral op die gebruik van die werkwoord 'peripateo' (in Grieks: $\pi \varepsilon \rho \imath \alpha \tau \eta े \sigma \alpha$ ) wat vyf keer in Ef. 4 en 5 gebruik word. ${ }^{5}$ Die 1983 vertaling van die Afrikaanse Bybel het dit met die pragtige woord 'lewenswandel' vertaal. In die nuwe direkte vertaling van die Afrikaanse Bybel word dit kort en kragtig vertaal met die opdrag: 'Leef!' Ons lees in die 1983 vertaling van Ef. 4:1: 'Laat julle lewenswandel in ooreenstemming wees met die roeping wat julle ontvang het ...' In die nuwe direkte vertaling lees ons: 'Ek spoor julle aan om so te leef dat julle die roeping waarmee julle geroep is, waardig is'. Ons kan die woord ook vertaal met 'navolging'.

In Ef. 5:1 word dié gedagte nog skerper beklemtoon deur dit te koppel aan die woord 'mimetai' (in Grieks: $\mu \mu \eta \tau \alpha i$ ), waarvan ons Afrikaanse woord 'mimiek' afkomstig is: 'Julle moet nabootsers ('mimetai') van God wees ${ }^{6} . .$. leef in liefde soos Christus ons liefgehad het en Homself ter wille van ons oorgegee het as 'n offergawe aan God ...' Hierdie woorde is in terme van betekenis identies aan 1 Petrus 2:21 wat sê: 'Juis hiervoor is julle geroep, omdat Christus self vir julle gely het en so vir julle 'n voorbeeld gestel het sodat julle in sy voetspore kan volg'. In hierdie konteks beteken die werkwoord 'peripateo' om 'in die voetspore van iemand te volg, om dieselfde as iemand anders te doen, om iemand anders na te boots' (vgl. Louw \& Nida 1989:509 [41.47]):

- Wat beteken dit om 'nabootsers van God', om nabootsers van Jesus Christus te wees?

- Wat beteken dit vir elkeen van ons, en in besonder vir die Hervormde Kerk, om mense van 'die Weg' te wees, om ons kruis op te neem en in Jesus se voetspore te volg?

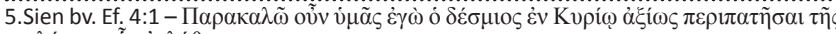

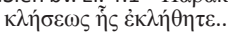

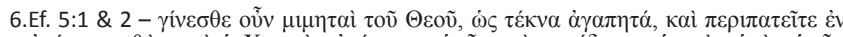

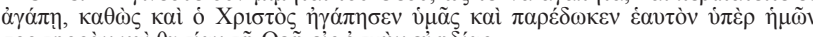

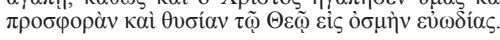

\section{Eksegetiese opmerkings}

Daar is verskil van mening onder Nuwe-Testamentici of die Brief aan die Efesiërs direk van Paulus afkomstig is. Waarskynlik is die Brief aan die Efesiërs van 'n latere outeur afkomstig (Bornkamm 1972 [1977]:245) wat in die Pauliniese tradisie gestaan het (Michaelis 1961:189-191) en verskillende tekste wat in die vroeë kerk in omloop was, verwerk het ${ }^{7}$ tot die teks wat ons vandag voor ons het. Die Brief aan die Efesiërs bevat nie net gedeeltes uit die Ou Testament nie, maar ook gedagtes en formulerings wat ons in ander NuweTestamentiese gedeeltes vind. Dit is veral Paulus se Brief aan die Kolossense (Engelbrecht 1995:686; Van Wyk 2015:2-3) wat aan die skrywer van die Brief aan die Efesiërs bekend was. Daarom vertoon die brief, teologies gesproke, heelwat ooreenkoms met die Brief aan die Kolossense (McNeile 1953 [1965]:167). Die skrywer herhaal ook gedagtes wat ons in die Eerste Brief van Petrus vind en gebruik ook liedere wat in die vroegste Christelike gemeentes gesing is. 'n Voorbeeld hiervan is die lied in Ef. 1:3-14. ${ }^{8}$ Daar vind ons 'n pragtige loflied oor God die Vader wat in sy genade en liefde ons in Jesus Christus gekies het, as sy kinders aangeneem het en deur die Heilige Gees verseker dat ons deel het aan die ewige erfenis wat God vir ons in bewaring hou.

Die Brief aan die Efesiërs kom uit'n tyd toe Jesus se volgelinge besig was om in verskillende dorpe rondom die Middellandse See geloofsgemeenskappe te vestig (Engelbrecht 1995:686687). Die geografiese uitbreiding van die vroeë kerk, die kulturele diversiteit tussen Jode, Grieke en Romeine, asook konflik met heidense godsdienste het daartoe gelei dat die vroeë kerk geworstel het met vrae oor die identiteit van die kerk, kerklike leierskap en die eenheid van die kerk - veral die eenheid tussen die kerk en die gekruisigde en opgestane Here Jesus Christus.

Die Brief aan die Efesiërs bestaan uit twee hoofdele (Schlatter 1963:199). Die eerste hoofdeel (Ef. 1 tot 3) handel oor wat die kerk is, die wese van die kerk. Daarom word die Brief aan die Efesiërs dikwels as teologiese nadenke oor die kerk beskryf (Engelbrecht 1995:690). Die tweede hoofdeel (Ef. 4 tot 6) handel oor die roeping van die kerk, dit wat die kerk moet doen. Uit hierdie struktuur word dit baie duidelik dat dit wat die kerk is, bepalend is vir dit wat die kerk doen. Om met integriteit kerk te wees, vra dat die kerk deur sy handeling sigbaar gestalte gee aan dit wat die kerk is.

Die eerste hoofdeel praat in pragtige en beeldryke geloofstaal, dikwels in die vorm van gebede en lofliedere, oor die kerk van Christus. Enkele belangrike gedagtes wat in die eerste hoofdeel na vore kom, is die volgende.

Eerstens: Die kerk is die uitverkore volk van God (1:11). Hierdie nuwe volk van God het genade uit sy hand ontvang omdat hulle deur die bloed van sy Seun verlos is (1:7). Ons is

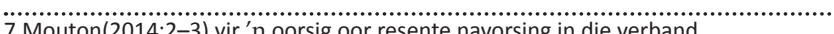

8.Vgl. Barkhuizen (1990). Prof. J.H Barkhuizen ontvang tydens die 71e Algemene Kerkvergadering die HCM Fourie Erepenning vir die bevordering van reformatoriese teologie. 
deel van die kerk omdat ons deur die krag van God saam met Christus uit die dood opgewek is sodat ons vir God kan leef (2:6). Ons is uit genade deur geloof gered (2:8).

Tweedens: Omdat ons met Christus een geword het in sy dood en opstanding (2:13), is alle gelowiges met mekaar een en is daar nie meer onderskeid tussen Jode of Grieke nie (2:14). Christus het die muur van vyandskap wat tussen mense bestaan, afgebreek. Almal is tot een, nuwe mensheid verenig in een liggaam, die liggaam van Christus wat die kerk is (2:16). Die ganse kosmos, ook die kerk, staan onder die heerskappy van Christus (3:10-11).

Derdens: Die beeld van die kerk as liggaam van Christus word in die Brief aan die Efesiërs ook gebruik om die groei van die kerk te beskryf (Van Wyk 2015:7). Die kerk is volgens die beeld 'n lewende organisme wat na die Hoof toe groei. Die liggaam groei deur die aandeel van elke lid (Ef. 4:16). Die groei van die kerk word beskryf as 'n groei tot ware kennis van die Seun van God. Daardeur kan die kerk sigbaar en volledig gestalte gee aan die liggaam van Christus (Ef. 4:13). Groei gaan nie in die eerste plek oor getalle nie, maar om inkarnerende groei - om meer en meer die liggaam van Christus te wees. Hierdie bevrydende perspektief help ons om verby krimpende getalle te kyk en die fokus te verskuif na 'n lewe in ooreenstemming met die roeping wat ons ontvang het, om as liggaam van Christus te leef.

Vierdens: Die Brief aan die Efesiërs artikuleer die verhouding tussen Christus en die kerk met 'n uitdrukking wat ons dikwels in die briewe van die apostel Paulus vind: Ons is in Christus! Gelowiges is ten nouste verbonde aan Christus, soos een liggaam. Hy is die hoof, ons die liggaamsdele. Die kerk is die liggaam van Christus, organies een met die Hoof en Heer van die kerk. Hierdie Christologiese en ekklesiologiese (Conzelmann \& Lindemann 1980:242-243) beginsel, dat ons as gelowiges en as kerk in Christus is, is die basis waarop die volgende drie hoofstukke bou.

In Calvyn se denke het die 'in Christus wees' 'n groot rol gespeel (Calvin 1559). Calvyn het sy persoonlike lewe en geloof gebou op die beginsel dat ons deur die krag van God 'in Christus' ingelyf is. Daarom kan ons as verloste mense leef; daarom kan ons in gehoorsaamheid aan God leef; daarom kan ons die liggaam van Christus wees. Die eenwees met Christus, volgens Calvyn, gebeur deur die vernuwende werk van die Heilige Gees in ons. Dit word ook sigbaar uitgebeeld in die sakramente, by die doop en nagmaal. Die doop verkondig dat ons in Christus ingelyf word; dat ons met Christus een is in sy dood en opstanding; die nagmaal gee deur die brood en wyn aan ons sigbaar die versekering dat ons deel het aan en deel is van Christus se liggaam.

Vyfdens: In die Brief aan die Efesiërs (2:19-22) vind ons naas die beeld van die kerk as liggaam van Christus ook 'n ander bekende beeld wat die apostel Paulus gebruik het: Die kerk is die tempel van God (1 Kor. 3:9-17). Die kerk is 'n gebou wat deur God op vaste fondamente opgerig is. Christus is die hoeksteen, gebou op die leer van die apostels omdat dit Christusgetuienis is.

Sesdens: In die Brief aan die Efesiërs vind ons ook 'n baie diep bewussyn dat die gelowiges individueel, en die kerk as geheel, in die eindtyd leef (vgl. Bekker 1990). Die kerk is nou reeds die liggaam van Christus en die tempel van God. Dit het betekenis vir die hede sowel as die toekoms. Die feit dat die kerk Jesus Christus 'beliggaam', het direkte gevolge vir die wyse waarop die kerk hier en nou leef.

Die tweede hoofdeel van die brief waaruit ons gedeeltes gelees het, bestaan uit praktiese riglyne vir die Christelike lewe, gebou op die beginsels wat in die eerste drie hoofstukke geformuleer is (Mouton 2014:2). Die vermanings en aanmoediging in hierdie tweede gedeelte vloei voort uit God se genade wat Hy in Christus aan die gelowiges en die kerk geskenk het. Die gelowiges word aangespoor om op 'n bepaalde manier te leef, om in Christus se voetspore te volg.

\section{Kerkwees in Christus se voetspore}

Maar wat beteken dit volgens Ef. 4 en 5 om in Christus se voetspore te volg?

Eerstens: Mense wat Jesus volg, leef eensgesind. In Ef. 4:1-6 word die volgelinge van Christus dit op die hart gedruk dat hulle in ooreenstemming met die roeping wat hulle ontvang het, moet leef .Die roeping en opdrag wat die kerk van God ontvang het, is om die eenheid wat God deur sy Gees tussen ons en al ons medegelowiges oor die wêreld gesmee het, sigbaar uit te leef. Dit verg selfverloëning en kruisdra, dit vra dat ons in liefde, sagmoedigheid, geduld en vrede met mekaar saamleef. Dit is die roeping en lewenstyl wat ons as gelowiges en as Hervormde Kerk in die wêreld sigbaar moet laat word. Dít is die kragtigste getuienis in 'n land wat gekenmerk word deur konflik, spanning en geweld.

In die Hervormde Kerk is al groter diversiteit sigbaar. Dit manifesteer in die liturgie, teologiese denke en ons verstaan van die werklikheid. Dit het in die onlangse verlede selfs op 'n kerkskeuring uitgeloop. Die Kommissie van die AKV het in die afgelope tyd baie tyd en energie spandeer om die eenheid van die kerk te bevorder. Diversiteit is belangrik vir die kerk. Dit is nie sonder rede dat ons lees dat die Heilige Gees aan ons 'n verskeidenheid van gawes (1 Kor. 12-14; Rom. 12:6 e.v.) gee nie. Maar ons mag nooit vergeet nie: Ons bely nie die diversiteit van die kerk nie, maar die eenheid. Ons is geroep tot eenheid. Die uitdaging voor hierdie Algemene Kerkvergadering is om te midde van diversiteit die eenheid wat die Gees tussen ons gesmee het, te handhaaf en te artikuleer. Dit is alleen moontlik as ons diep bewus is daarvan dat ons almal in Christus ingelyf is, dat ons met Christus een geword het in sy dood en opstanding en daarom die een liggaam van die Here Jesus Christus is.

Tweedens: Mense wat Jesus volg, leef heilig. In Ef. 4:17 word die volgelinge van Christus vermaan om nie soos heidene te leef nie. Van vers 22 af lees ons: 
Julle het Christus nie so leer ken nie. Julle het tog van Hom gehoor en julle is oor Hom onderrig, volgens die waarheid wat in Jesus is ... Julle moet deur die aard van julle denke vernuwe word ... Trek die nuwe mens as kleed aan wat in ware heiligheid na God se beeld geskep is ...

Die nuwe kleed waarvan vers 24 praat, word in die volgende verse gedefinieer as 'n lewe met integriteit, 'n lewenstyl gekenmerk deur eerbaarheid, selfbeheersing, innige meelewing met mekaar en wedersydse vergifnis.

Volgelinge van Christus kyk op 'n nuwe manier na die wêreld, dink op 'n nuwe manier en doen op 'n nuwe manier. Die aard van ons denke is anders, die inhoud van ons denke is anders ... Ons denke word bepaal deur die evangelie van Jesus Christus. As die Hervormde Kerk met integriteit kerk wil wees, moet ons mekaar konfronteer met die vraag: Word ons denke bepaal deur die evangelie, of deur die wêreld? Is ons bereid om die nuwe kleed van heiligheid aan te trek, om te leef as mense wat na die beeld van God geskep is?

Om met integriteit kerk te wees, om Luther se woorde te gebruik, vra dat die kerk erns sal maak met 'n lewe van coram Deo, coram hominibus. Hoe leef die kerk voor die aangesig van God én voor die aangesig van mense? Die Hervormde Kerk het nog altyd erns gemaak met 'n lewe voor die aangesig van God, maar somtyds minder erns gemaak met 'n lewe voor mense. Toe die AKV hom uitgespreek het oor ongeregtigheid in die Suid-Afrikaanse samelewing, is dit geëtiketteer as ekumenisme, kommunisme en bevrydingsteologie.

Tog ontkom ons nie aan die radikale eis om heilig te leef nie. In Christus is ons reeds heilig - ons moet dit ook sigbaar uitleef. Dit vra daaglikse bekering tot 'n lewe van toewyding en gehoorsaamheid aan God; bekering van luiheid, kwaadwilligheid en onetiese optrede wat die integriteit van die kerk en die geloofwaardigheid van die evangelie op die spel plaas.

Derdens: Mense wat Jesus volg leef in liefde. In Ef. 5:1 lees ons: 'Wees nabootsers van God en leef in liefde, net soos Christus ons liefgehad en Homself ter wille van ons oorgegee het as 'n offergawe aan God ...' Mense van die Weg ken God se liefde, ken God as die Een wat die wêreld so lief gehad het (Joh. 3:16) dat Hy sy enigste Seun gestuur het om die wêreld met Hom te versoen.

Jesus het ons geleer om God en ons medemens lief te hê. Dit is die Groot Gebod. Jesus het sy boodskap bevestig deur mense in hulle nood aan te raak en te versorg. Jesus se volgelinge het ook by die nood van mense in hulle gemeenskap betrokke geraak. Met die uitbreek van epidemies het Christene gehelp om siekes te versorg; na oorlog of gevegte het hulle die soldate wat gesneuwel het, begrawe; hulle het hulle kos met armes gedeel; hulle het die weduwees versorg (Eusebius, in Schaff \& Wace 1961:362-363). Die feit dat baie Christene in die proses siek geword en self gesterf het, het die geloofwaardigheid en integriteit van die Christene bevestig.
Die tyd het aangebreek dat gemeentes hulle roeping om as agente van God se liefde in hierdie wêreld op te tree, met groter erns en toewyding uitleef. Elke gemeente van die Hervormde Kerk is deur God geroep om mense in hulle fisiese en geestelike nood te ondersteun. Hierdie diensbaarheid is gehoorsaamheid aan God wat ons beveel het: Wees barmhartig, want Ek is barmhartig ... Die liefdesdiens van gemeentes vloei voort uit die wese van God self, die God waarvan Johannes (1 Joh. 4:8) getuig dat Hy Liefde is. Die kragtigste getuienis van die kerk is om waarlik kerk te wees: 'n Kerk waar liefde, barmhartigheid en deernis met mense in nood ons aan die hart gryp.

Vierdens: Mense wat Jesus volg, lewe in die lig. In Ef. 5:8 word die volgelinge van Christus aangemoedig om te 'lewe as mense van die lig'. Uit die lig kom alles wat goed en reg en waar is.

In hierdie gedeelte word die kerk aangemoedig om noukeurig te onderskei wat vir God goed, aanneemlik en reg is. Die gawe van onderskeiding is een van die besondere gawes wat die Heilige Gees aan die kerk gee. In 1 Kor. 12:10, waar Paulus handel oor die gawes van die Heilige Gees, skryf hy: 'Aan 'n ander gee Hy (die Gees) die gawe om tussen die geeste te onderskei.'

Hoe onderskei ons, onder leiding van die Gees, wat vir God reg en goed is? Dit is die uitdaging waarvoor hierdie Algemene Kerkvergadering staan. In ons gesprekke en besluitneming het ons net een verantwoordelikheid, dit is om te onderskei waarop dit aankom, om te onderskei wat God se wil is, om te onderskei wat die waarheid is. Hier gaan dit nie om my en jou idee van die waarheid nie, nog minder is die AKV 'n politieke vergadering waar die demokraties verkose meerderheid se wil bepalend is nie. Hier gaan dit om een vraag: Wat verwag God van ons? Ons verantwoordelikheid is om die lig van die evangelie te laat val op baie moeilike en komplekse sake.

Genadiglik het die Hervormde Kerk nog altyd 'n bepaalde verstaan van die waarheid gehad. Waarheid word nie vasgevang in 'n stel reëls, in dogmas of in groot besluite van kerklike vergaderings nie. Hierdie Algemene Kerkvergadering beskik nie oor die waarheid nie. Die waarheid wat ons bely is ' $n$ Persoon: Dit is Jesus Christus van wie ons bely dat Hy die 'Weg en die Waarheid en die Lewe is'. In ons gesprekke en besluitneming moet dit wat Jesus ons geleer het die deurslag gee. Hy is die Waarheid, Hy is die Lig vir die wêreld (Joh. 1). Daardie Lig moet ons help om ons pad te vind. In daardie Lig kan ons leef en werk.

Laastens: Mense wat Jesus volg, leef met wysheid. In Ef. 5: 15 word Jesus se volgelinge vermaan om met wysheid te leef:

Let daarom sorgvuldig daarop hoe julle leef - nie as onverstandiges nie, maar as wyse mense ... Moenie onverstandig wees nie, probeer eerder verstaan wat die wil van die Here is.

Om in Jesus se voetspore te volg, beteken om met wysheid te leef. In die Bergrede (Matt. 5-7) het Jesus ons geleer wat 
dit beteken om met wysheid te leef. Hy sluit die Bergrede af met die bekende woorde:

Elkeen dan wat na My woorde luister en daarvolgens leef, kan vergelyk word met 'n wyse man wat sy huis op rots gebou het. Stortreën het geval, stormwind het gewaai, maar die huis se fondament was op rots ...

Wysheid is om te luister na Jesus se stem, om te luister na wat die Gees vir die gemeente sê, om vreugde te vind in die Woord van God (Psalm 1). Jesus Christus se volgelinge luister en leer by Hom, sodat hulle met wysheid kan leef en praat en doen. As ons met erns na die Here Jesus luister, sal ons vind dat ons huis ook op rots gebou is.

\section{Slot}

Die Brief aan die Efesiërs is 'n aangrypende teks wat kortkort oorborrel van entoesiasme oor die kerk, omdat die kerk die volk van God is, kinders van die Vader, die liggaam van Christus en die tempel van die Heilige Gees.

Die Hervormde Kerk het die afgelope twintig jaar intens geworstel oor die identiteit en roeping van die Kerk in die een en twintigste eeu. Op vergaderings, in dokumente van die kerk en in kerklike publikasies het ons met mekaar gepraat oor missionale kerkwees, praktiese omstandighede van gemeentes, hersiening van die Kerkorde, volkskerk en die Kerk se openbare getuienis in post-apartheid Suid-Afrika.

Ek is van mening dat die Hervormde Kerk, gesien vanuit 'n historiese perspektief, 'n bepaalde draaipunt bereik het. 'n Era in die geskiedenis van die Hervormde Kerk is afgesluit, ' $n$ nuwe era het aangebreek. Ons het vir baie dekades op 'n bepaalde manier oor die kerk en kerkwees gedink en gepraat. Die tyd (kairos, Mark. 1:15) het aangebreek om ons fokus te verskuif. Ons kan nie meer net na binne kyk nie. Ons kan nie meer net oor onsself bekommerd wees nie, oor die instandhouding van die Kerk nie. Ons moet Christus ín die wêreld ín volg, getrou aan die roeping wat ons van Hom ontvang het.

Ek is van mening dat die eenvoudige beeld, dat ons in Christus se voetspore moet volg, ons kan help om op 'n nuwe en geloofwaardige wyse kerk te wees, om met integriteit te leef en te getuig van God se liefde. Die Brief aan die Efesiërs rig 'n kragtige appèl tot Christene deur al die eeue dat hulle in Christus se voetspore moet volg. Ons moet leef en praat en doen soos Jesus Christus ons geleer het. Om in Jesus Christus se voetspore te volg beteken dat ons na Hom sal luister, by Hom sal leer en volgens God se wil sal leef.

\section{Erkenning Mededingende belange}

Die outeur verklaar dat hy geen finansiële of persoonlike verbintenis het met enige party wat hom nadelig kon beïnvloed het in die skryf van hierdie artikel nie.

\section{Literatuurverwysings}

Aland, K. \& Metzger, B.M. (ed.), 1975, The Greek New Testament, United Bible Societies, Stuttgart.

Augustinus, A., [397] 1954, Belijdenissen, vert. Th. P. Van Baren, Erven J. Bijleveld, Utrecht.

Barkhuizen, J.H., 1990, 'The strophic structure of the eulogy of Ephesians 1:3-14', HTS 46(3), 390-413.

Barth, K., 1968, Epistle to the Romans, vertaal deur Edwin C. Hoskyns, Oxford University Press, Oxford.

Bornkamm, G., 1972 [1977], Paulus, Derde Uitgawe, Verlag W. Kohlhammer, Stuttgart.

Bybelgenootskap van Suid-Afrika, Die Bybel in AfrikaansDirekte Vertaling, teks van die Efesierbrief te vind by http://www.bybeldirektevertaling.co.za/images/stories/ docs/efesiers2.pdf

Calvin, J., 1559, 'Institutio Christianae Religionis', in E. Cunitz, E. Baum, J.W. Reuss \& E.W. Eugen (eds.), Corpus Reformatorum Vol. XXX Joannis Calvini opera quae supersunt omnia Vol. II, (1864), O.A. Schwetschke et Filium, Brunsvigae.

Conzelmann, H., 1981, 'Der Brief an die Epheser', in Neue Testament Deutsch, pp.86-124, Vandenhoeck \& Ruprecht, Göttingen.

Conzelmann, H.\& Lindemann, A., 1980, Arbeitsbuch zum Neuen Testament, J.C.B. Mohr (Paul Siebeck), Tübingen.

Dreyer, T.F.J., 1995, 'Implikasies van die kommukatiewe handelingsteorievir ' prakties-teologiese perspektief op die ekklesiologie', HTS Teologiese Studies 51(3), 792-805.

Engelbrecht, J.J., 1995, 'Opmerkings oor vroee katolisisme in die Nuwe Testament, met besondere verwysing na die briewe aan die Kolossense en die Efesiers, en die Pastorale Briewe', HTS 51(3), 677-701.

Hoehner, H.W., 2002, Ephesians - An exegetical commentary, Baker Academic, Grand Rapids, MI.

Lemmer, H.R., 1990, 'A multifarious understanding of eschatology in Ephesians: A possible solution to a vexing issue', HTS 46(1 \& 2),102-119.

Luther,M., 1537[2005], 'The Smalcald Articles II/1', in Concordia: The Lutheran Confessions, p. 289, Concordia Publishing House, Saint Louis, MO.

McNeile, A.H., 1953 [1965], An introduction to the study of the New Testament, 2nd edn., 5th Impression, Clarendon Press, Oxford.

Michaelis, W., 1961, Einleitung in das Neue Testament, Berchtold Haller Verlag, Bern.

Mouton, E., 2014, “'Ascended far above all the heavens": Rhetorical functioning of Psalm 68:18 in Ephesians 4:8-10?', HTS Teologiese Studies/Theological Studies70(1), Art. \#2058, 1-9. https://doi.org/10.4102/hts.v70i1.2058

Nel, R.W., 2015, 'The role of urban religion in seeking peace beyond the mere absence of community conflict: A reading of Eph 2:11-22, with the homeless in the City of Tshwane', HTS Teologiese Studies/Theological Studies 71(3), Art. \#3128, 1-8. https://doi.org/10.4102/hts.v71i3.3128

Schaff, P. \& Wace, H. (ed.), 1961, 'The life and writings of Eusebius', in Nicene and postnicene fathers series II/Vol. 1, Eusebius, WM. B. Eerdmans Publishing Comapany, Grand Rapids, MI.

Schlatter, A., 1963, 'Die Briefe an die Galater, Epheser, Kolosser und Philemon', in Erläuterungen zum Neuen Testament Band 7, Calwer Verlag, Stuttgart.

Van Huyssteen, W., 1986, Teologie as kritiese geloofsverantwoording, Raad vir Geesteswetenskaplike Navorsing, Pretoria.

Van Roon, A., 1976, 'Die Brief aan de Efeziërs', in De Prediking van het Nieuwe Testament, Uitgeverij G.F. Callenbach B.V., Nijkerk.

Van Wyk, B., 2015, 'Die verhouding tussen Kolossense en Efesiërs as 'n sinoptiese probleem', HTS Teologiese Studies/Theological Studies 71(3), Art. \#3067, 1-7. https://doi.org/10.4102/hts.v71i3.3067 